\title{
POTENTIAL FOR A NEW MULTIMILLENNIAL TREE-RING CHRONOLOGY FROM SUBFOSSIL BALKAN RIVER OAKS
}

\section{CHARLOTTE L. PEARSON ${ }^{1 *}$, TOMASZ WAŻNY ${ }^{1,2}$, PETER I. KUNIHOLM ${ }^{1}$, KATARINA BOTIĆ ${ }^{3}$, ALEKSANDAR DURMAN ${ }^{4}$, and KATHERINE SEUFER ${ }^{5}$}

${ }^{1}$ Laboratory of Tree-Ring Research, University of Arizona, 1215 E. Lowell Street, Tucson, AZ 85721, USA.

${ }^{2}$ Institute for the Study, Conservation and Restoration of Cultural Heritage, Nicolaus Copernicus University, ul. Sienkiewicza 30/32, 87-100 Toruń, Poland.

${ }^{3}$ Institute of Archaeology, Ljudevita Gaja 32, HR-10000, Zagreb, Croatia.

${ }^{4}$ Department of Archaeology, Faculty of Humanities and Social Sciences, University of Zagreb, Ivana Lučića 3, HR-10000, Zagreb, Croatia.

52699 Derby Street, Apt. 1, Berkeley, CA 94705, USA.

*Corresponding author: c.pearson@1trr.arizona.edu.

\begin{abstract}
A total of 272 oak (Quercus sp.) samples have been collected from large subfossil trees dredged from sediment deposited by the Sava and various tributary rivers in the Zagreb region of northwestern Croatia, and in northern Bosnia and Herzegovina. Measurement series of tree-ring widths from these samples produced 12 groups, totaling 3456 years of floating tree-ring chronologies spread through the last ca. 8000 years. This work represents the first step in creating a new, high-resolution resource for dating and paleoenvironmental reconstruction in the Balkan region and potentially a means to bridge between the floating tree-ring chronologies of the wider Mediterranean region and the continuous long chronologies from central Europe.
\end{abstract}

Keywords: subfossil oak, dendrochronology, Balkans, paleoclimate.

\section{INTRODUCTION}

The Sava River represents the northwestern boundary of the Balkan Peninsula. Its basin, with numerous tributary rivers, covers a large area from the southern edges of the Alps, the southern part of the Pannonian lowland, and the northeastern part of the Dinaric Mountains. Rivers in this region have a history of wide-scale flooding, as commonly witnessed in recent years (e.g. Begović and Schrunk 2010; extensive media coverage in 2014). Over time, as river channels meander across their flood plains, layers of gravel and sand carried by various floods build up, and in such deposits it is not uncommon to find well-preserved "subfossil" trees. The term subfossil indicates the potential for the wood to have been preserved for a very long time, but suggests that no replacement of the woody structure, i.e. true fossilization, has begun. Such trees began life growing on forested river banks, which were undercut by flood waters. As the banks collapsed, the trees fell into the heavy flow of water and suspended sediment and were transported downstream to be deposited as the flow abated. With the trees sealed in water-logged sediment, the low oxygen environment can preserve them for long periods of time until they are re-exposed by new river channels or human activity. This is the scenario in our study areas in the Zagreb region of northwestern Croatia, and the Orašje and Vrbas River regions in northern Bosnia and Herzegovina (see Figure 1), where subfossil trees are being extracted from relict and active river channels for commercial use. This wider region has complex hydrological conditions. The area between Orašje and Osijek to the north in Croatia was regularly flooded by discharge waters from the Alps or Bosnian Mountains until the end of the 19th century, remaining under water for long periods of each year. From the end of the 19th century, floods were regulated by melioration systems, but nevertheless there are seasons when floods occur, depending on weather conditions in the wider region. Less often, the excess water comes down the Danube River from central Europe. Trees from such deposits across Europe have proven immensely valuable for a wide range of scientific research and have provided the backbone of many significant long tree-ring chronologies (e.g. Becker and Delorme 1978), perhaps most famously of all in the case of the combined Hohenheim chronology (e.g. Becker 1982, 1983, 1993), an oak (Quercus sp.) and pine (Pinus sp.) tree-ring chronology from central Europe that provides an annual, absolutely dated tree-ring timescale back to $8480 \mathrm{BC}$ (Friedrich et al. 2004). This is currently the world's longest continuous sequence of tree rings and, as with other such long tree-ring records (e.g. Ferguson 1969; Pilcher et al. 1984; Brown et al. 1986; Eronen et al. 2002; Grudd et al. 2002; Fowler et al. 2004; Cook et al. 2006; Salzer et al. 2009), it offers an invaluable data set for dating wood from archaeological sites and historical artifacts (e.g. Becker 1983; Tegel et al. 2012). It also offers a high-resolution paleoenvironmental resource (Spurk et al. 1998; Leuschner et al. 2000) and, critically, has provided a backbone for calibration of the ${ }^{14} \mathrm{C}$ record (Linick et al. 1985; Spurk et al. 1998; Friedrich et al. 2004). 


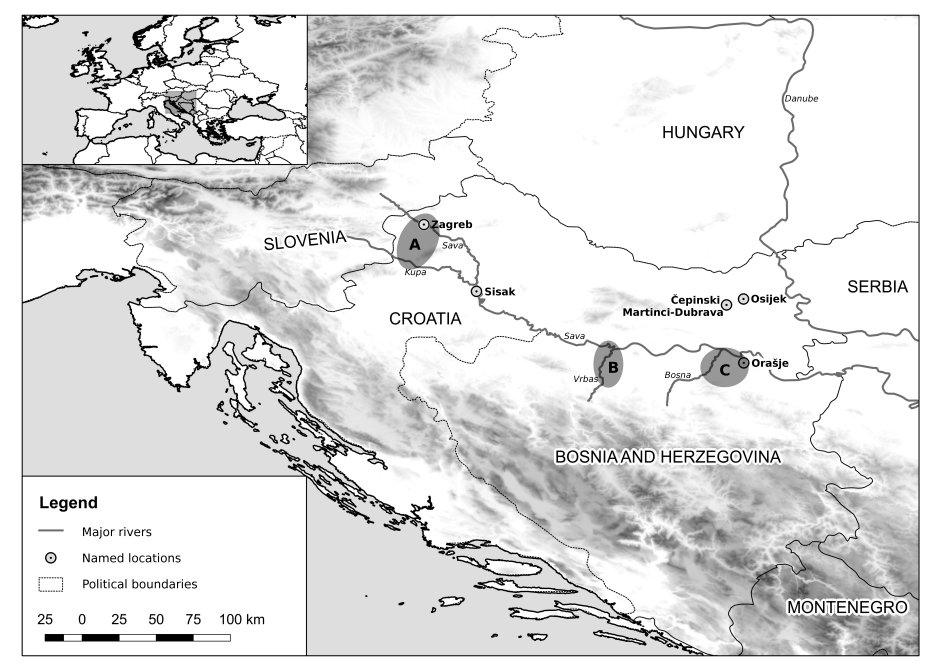

Figure 1. Map of study region with widely spaced sampling locations. Area A, Zagreb region, Krapina, Sava and Kupa river gravel; Area B, Vrbas river gravels; and Area C, Bosna river gravels and the Oštra Luka gravel beds.

Our study region is located at the transition between the Mediterranean and continental climatic influence, making it a significant area to explore crossmatching potential for linking or bridging between the major North European tree-ring chronologies and data sets from the Mediterranean. In this issue, Ważny et al. (2014) have demonstrated such a link through a north-south transect between Poland and northwestern Turkey.

Potential to crossmatch material from Croatia with oak growth in the wider region is indicated by the climatological studies of Čufar et al. (2014), which identified common climatic controls of oak growth at sites in Austria, Hungary, Slovenia, Croatia, and Serbia, from $45.00^{\circ}$ to $48.00^{\circ} \mathrm{N}$ latitude and from $13.14^{\circ}$ to $21.63^{\circ} \mathrm{E}$ longitude. They demonstrated that wet springs and summers, especially for the months of March and June, as well as a cool April and June, improved growth of oak ring widths at these sites. Similarly, correlations between the Roman period oak chronologies from Celje in Slovenia and Sisak in Croatia indicate excellent potential to crossdate oaks from different parts of the Balkan Peninsula (Durman et al. 2009). Such teleconnections have proved advantageous in the construction of many oak chronologies from sites across north-central Europe (Baillie 1983; Pilcher et al. 1984; Ważny and Eckstein 1991; Haneca et al. 2005; Kolar et al. 2012).

A systematic program of dendrochronological research in Croatia/Bosnia and Herzegovina is just beginning, though in neighboring Slovenia, Čufar et al. (2008) have constructed an oak tree-ring chronology spanning the period AD 1456-2003, which illustrates some exciting potential for constructing and crossmatching long regional chronologies. Correlations are demonstrated between tree-ring width patterns over large distances (up to $700 \mathrm{~km}$ away) as well as "heteroconnections" between treering patterns in oak and other species such as silver fir (Abies alba), beech (Fagus sylvatica L.), and ash (Fraxinus excelsior L.) in the same region. In light of this, a further avenue of exploration for future work may also include the Nicolussi et al. (2009) 9111-year-long conifer chronology for the east European Alps, given that the Sava drains this region. Our primary focus, however, will be on oak chronologies of the wider region such as those constructed by Kuniholm (2008) for the periods AD 1534-1850 and 1073-1351.

Working with a number of dredging companies along the Krapina, Sava, Bosna, and Vrbas rivers and the Oštra Luka gravel beds, we have obtained 272 samples from large subfossil oak trees. At least two different subspecies of oak are present, most likely Quercus robur L. (pedunculate oak) and Quercus petraea Liebl. (sessile oak), though working with wood anatomy alone (i.e. no preserved bark, leaves or acorns to aid in the identification) it has not been possible to make exact subspecies determinations. Ufnalski (2006) and Cedro (2007) have demonstrated that these two subspecies can respond very similarly to the same climatic variables, however, making crossmatching of tree-ring patterns between the two perfectly viable.

Oak is arguably the single most important genus for European dendrochronology and its use and usefulness for the study of Europe's wooden cultural heritage has been thoroughly reviewed (Čufar 2007; Haneca et al. 2009). It has been a dominant woodland species across central Europe since 12,000 BP (Sadori et al. 2011), growing under a wide variety of ecological conditions (Ducousso and Bordacs 2004), and, as it is durable and resistant to decay (Haneca et al. 2005), the preservation of a wide temporal spread of material for a given region is very possible.

Oak also offers a potential for exact dating because, for specific subspecies in particular regions, the approximate number of sapwood rings before the bark has been shown to be predictable (e.g. Hillam et al. 1987; Kuniholm and Striker 1987; Ważny 1990; Eckstein 2007; Griggs et al. 2009). This means that where the last ring under the bark is not preserved to provide an exact cutting date, if any sapwood is present it is possible to improve on a terminus post quem date for the last measured year by making an informed estimate as to the likely number of missing sapwood rings (see Kuniholm 2001). Where the last ring under the bark (terminal ring or "waney edge") is present, dating precision with oaks can be exact to a particular season depending on the degree of cell formation observed (Eckstein 2007; Gričar 2010, 2013). Unfortunately, in the abrasive context of our riverine burial environments, sapwood preservation is extremely rare. On the whole, though, there is excellent potential for these oak samples to connect with more recently grown material to build a new multimillennial oak master chronology for the Balkans. In this scenario, the value of such a resource for producing a chronological framework for archaeological and paleoenvironmental sites in the region is clear. But, beyond this, there is also a possibility that such an archive could provide a bridge to help resolve some of the major chronological issues in the dendrochronologically difficult Mediterranean region. 


\section{Site Description}

Sampling locations are spaced across a wide region (Figure 1) with drier conditions in the eastern plains of Croatia and wetter conditions (by ca. $300 \mathrm{~mm}$ ) to the west around Zagreb. Area A, the Zagreb region, includes materials from the Krapina, Sava, and Kupa river gravels. This area is situated in the pre-Alpine zone with modern climate conditions similar to those in Slovenia. Areas around upper flows of the Kupa and Krapina rivers today are densely forested with a mixture of woodland species including oak $(Q$. petraea). The midsections of these rivers are situated in the plains with no forestation, while the lower flow of the Kupa is again forested. The Sava River passes through very diverse landscapes from its upper flow until close to the Slovenian-Croatian border.

Area B includes a range of Vrbas River gravels. The Vrbas River flows from the central Bosnian territory through a mountainous region in the south with mixed oak forest (again dominated by Q. petraea) to the plain in the north where it enters the Sava. The plain near the Sava is large and filled with traces of old gravel beds. The present-day river flows along its eastern edge.

Area $\mathrm{C}$ includes samples from both Bosna River gravels and the Oštra Luka gravel beds. The Bosna River follows a similar route to the Vrbas, flowing from the central Bosnian territory to the east. It runs through the mountain region in the south to the plain in the north where it enters the Sava near Šamac. The lower flow across the plain is very unstable, often changing course during the year, depending on the amount of precipitation. The Oštra Luka gravel beds are situated east of the Bosna and southwest from the town of Orašje. It is not clear whether the Oštra Luka gravel beds were originally laid down by the Bosna or Sava; however, samples from this location were retrieved from the greatest depths (up to $10 \mathrm{~m}$ ). Areas of the Vrbas and Bosna rivers are influenced by continental mountain climate with periodic heavy precipitation, especially in spring and autumn.

\section{METHODS}

One limitation to this preliminary study is that in the majority of cases the material was not collected directly from an in situ stratigraphic context by our research team. Instead, we are working with a number of commercial extraction companies and much of the sampled material had already been removed to a workshop. The result is that our data cannot be used quite as usefully as they might have been in determining their paleoenvironmental context, nor do we have ideal control over sampling (e.g. to try to include the pith and outermost rings), especially in some cases where samples had to be taken from precut timbers. Nevertheless, for the majority of samples, sections were selected from whole trees and we recorded as much relevant metadata as possible (e.g. site location, river/quarry, species, condition of the sample, presence or absence of sapwood/pith, proximity of the sample slice to the root system, presence of density fluctuations, scars and growth release events) using the Tree-Ring Data Standard (TRiDaS) (Jansma et al. 2010). Once a robust master chronology is established, we hope that it will be possible to conduct a systematic sampling campaign at separate extraction sites, sampling material in situ along with detailed descriptions of their sedimentary context in order to maximize the potential of the new data set.

Sample surfaces were prepared for analysis by sanding with successively finer grades of abrasive paper to produce a high polish so that boundaries between the tree rings could be clearly identified. Precise measurements (ca. $0.01 \mathrm{~mm}$ ) were made for each growth ring present in every sample using a light-reflected microscope, digitized Velmex measuring platform, and Tellervo software (http://www.tellervo.org; Brewer et al. 2010; Brewer 2014). Where practical, multiple radii were measured to check for reproducibility of ring-width measurements and to combat idiosyncrasies in the growth pattern. Tree-ring series representing individual samples were then compared (crossmatched) with one another using visual and statistical methods. Where significant matches were found ( $\mathrm{t}$-scores over 5 , on more than 50 years of overlap, plus a clear visual correlation), series were combined into groups that were then compared with a range of established oak tree-ring sequences (including subfossil material from the Danube River). Unfortunately, no definite crossmatches could be found to produce absolute tree-ring dates for these groups, so decades of tree rings from the beginning, midsection, and/or end of each group were selected for ${ }^{14} \mathrm{C}$ analysis. Careful notation was made of the number of years between decades so that the sequence of dates produced could be wiggle-matched to increase precision (Bronk Ramsey et al. 2001). ${ }^{14} \mathrm{C}$ analysis was carried out at the University of Arizona AMS Laboratory using standard procedures (Jull et al. 2008). Details of the AMS calculations for error at Arizona are given by Donahue et al. (1990) and Burr et al. (2007). Resulting data were calibrated to IntCal13 (Reimer et al. 2013) using OxCal v 4.2.3 (Bronk Ramsey 2009) and wiggle-matched as applicable.

\section{RESULTS}

All samples collected and crossmatched were Quercus sp., possibly because this material is being preferentially extracted to make furniture. Of these, $45.5 \%$ produced crossmatches with other samples resulting in 15 distinct groups. This relatively high percentage of matching material was approached with caution as, in a few instances, wood sampled at a particular workshop likely came from the same source tree. In most cases, we were able to obtain good information about the origin of each sample, but to mitigate against the possibility of duplication (in the absence of quality metadata), direct micro- and macroscopic visual comparisons were made between all samples included in the same chronologies. Thus, it was possible to confirm (in the majority of cases) whether any samples were from the same tree. Aside from conventional anatomic considerations, an additional factor that was helpful in this regard is the preservation quality of the samples, which is generally very good but features some distinctive shades of darker coloration. Where the same source of tree was confirmed or strongly suspected on the basis of several types of observation, measurement series were combined to represent one individual for incorporation into the larger chronologies. 
Tables 1 and 2 provide details on the numbers of sample per group, and their relative dating placements according to the ${ }^{14} \mathrm{C}$ group or chronology, the length of years represented by each analysis.

Table 1. The groups of matching tree-ring series ordered from oldest to youngest. The number of tree-ring years represented by each floating sequence, the number of samples making up the group, and the calibrated range of years $\mathrm{BC}$ or $\mathrm{AD}$ for the end decade or wiggle-matched placement for each group.

\begin{tabular}{rlcl}
\hline Group & Number of years & $\begin{array}{l}\text { Number of } \\
\text { samples }\end{array}$ & $\begin{array}{l}\text { Calibrated end date for floating group cal AD/BC } \\
(95 \% \text { confidence) (IntCal13) }\end{array}$ \\
\hline 10 & 215 & 4 & $5983-5747 \mathrm{BC}$ \\
14 & 233 & 2 & $3627-3353 \mathrm{BC}$ \\
3 & 453 & 42 & $2113-1965 \mathrm{BC}$ \\
1 & 321 & 29 & $1588-1551 \mathrm{BC}$ \\
7 & 166 & 3 & $798-519 \mathrm{BC}$ \\
6 & 116 & 3 & AD 258-543 \\
5 & 168 & 7 & AD 541-648 \\
15 & 300 & 2 & AD 1023-1189 \\
4 & 201 & 4 & AD 1018-1155 \\
2 & 258 & 8 & AD 1030-1206 \\
13 & 215 & 2 & AD 1278-1406* \\
8 & 287 & 2 & $* *$ \\
9 & 275 & 11 & $* *$ \\
11 & 152 & 4 & \\
12 & 196 & 5 & \\
\hline
\end{tabular}

*Possible dendrochronological placement ending AD 1334 against subfossil oaks from the Rhine, t-score 5.2, R 0.30, 287-year overlap. **Results pending (possible dendrochronological fit at $664 \mathrm{BC}$ relative to the Danube oak chronology, t-score 5.1, R 0.3, 275-year overlap).

Table 2. The uncalibrated and calibrated range of years BP for each decadal sample analyzed. In addition to the matching groups, three single pieces, which offer good future dating potential, were selected for ${ }^{14} \mathrm{C}$ analysis.

\begin{tabular}{|c|c|c|c|c|c|c|}
\hline \multirow{2}{*}{$\begin{array}{l}\text { Arizona AMS } \\
\text { lab code }\end{array}$} & \multirow{2}{*}{ Sample ID } & \multirow{2}{*}{$\begin{array}{l}{ }^{14} \mathrm{C} \text { age } \\
(\mathrm{BP})\end{array}$} & \multirow{2}{*}{$\begin{array}{l}\delta^{13} \mathrm{C} \\
(\%)\end{array}$} & \multicolumn{2}{|c|}{ Calibrated date BP (IntCal13) } & \multirow[b]{2}{*}{ Group } \\
\hline & & & & $68 \%$ confidence & $95 \%$ confidence & \\
\hline AA99705 & ORAS-25 & $7118 \pm 51$ & -26.4 & $7997-7874$ & $8021-7843$ & Single sample \\
\hline AA99708 & ORAS-14D & $929 \pm 39$ & -24.8 & 908-797 & $925-784$ & Single sample \\
\hline AA99730 & ORAS-123 & $1674 \pm 39$ & -25.8 & $1616-1535$ & $1699-1423$ & Single sample \\
\hline AA99727 & ORAS-141A & $3393 \pm 41$ & -23.8 & $3691-3586$ & $3822-3511$ & 1 \\
\hline AA99726 & ORAS-141B & $3270 \pm 41$ & -23.9 & $3560-3453$ & $3585-3396$ & 1 \\
\hline AA99728 & ORAS-60A & $3502 \pm 41$ & -25.1 & $3834-3718$ & $3886-3646$ & 1 \\
\hline AA99729 & ORAS-60B & $3397 \pm 41$ & -26.5 & $3692-3590$ & $3823-3514$ & 1 \\
\hline *Hd-30155 & ORAS-92A & $3312 \pm 17$ & -26.3 & $3572-3495$ & $3581-3478$ & 1 \\
\hline AA99724 & ORAS-20B & $962 \pm 38$ & -25.3 & $928-800$ & $937-788$ & 2 \\
\hline AA99725 & ORAS-55 & $1245 \pm 40$ & -25.9 & $1265-1091$ & $1275-1070$ & 2 \\
\hline AA99718 & ORAS-139A & $3705 \pm 42$ & -25.5 & $4140-3982$ & $4215-4155$ & 3 \\
\hline AA99719 & ORAS-139B & $3650 \pm 42$ & -27.2 & $4074-3901$ & $4090-3856$ & 3 \\
\hline AA99720 & ORAS-152 & $3754 \pm 43$ & -26.3 & 4223-3999 & $4240-3982$ & 3 \\
\hline AA99721 & ORAS-120A & $3851 \pm 43$ & -26.4 & $4400-4159$ & $4414-4151$ & 3 \\
\hline AA99722 & ORAS-120B & $3881 \pm 43$ & -26 & $4406-4256$ & $4420-4157$ & 3 \\
\hline AA99716 & ORAS-129 & $1313 \pm 39$ & -24.6 & $1290-1186$ & $1299-1180$ & 4 \\
\hline AA99717 & ORAS-39 & $998 \pm 38$ & -22.9 & 960-804 & $973-796$ & 4 \\
\hline AA99715 & ORAS-140:1003-1012 & $1625 \pm 39$ & -24.7 & $1565-1417$ & $1607-1411$ & 5 \\
\hline AA99714 & ORAS-140:1155-1164 & $1468 \pm 39$ & -24.8 & $1383-1315$ & $1513-1295$ & 5 \\
\hline AA99713 & ORAS-136 & $1641 \pm 51$ & -23.9 & $1610-1419$ & $1693-1407$ & 6 \\
\hline AA99712 & ORAS-114 & $2520 \pm 41$ & -26 & $2736-2503$ & $2747-2468$ & 7 \\
\hline AA99711 & ORAS-147-A & $640 \pm 51$ & -25.7 & $622-559$ & $673-544$ & 8 \\
\hline AA99706 & ORAS-151 & $6980 \pm 50$ & -25.5 & $7921-7750$ & $7932-7696$ & 10 \\
\hline AA99707 & ORAS-118 & $913 \pm 38$ & -26.3 & $907-788$ & $920-744$ & 13 \\
\hline AA99709 & ORAS-17A & $4654 \pm 45$ & -24 & $5462-5316$ & $5576-5302$ & 14 \\
\hline AA99710 & ORAS-40 & $1035 \pm 38$ & -24.9 & $975-923$ & $1055-804$ & 15 \\
\hline
\end{tabular}

*Single sample analyzed at the Heidelberg Laboratory; the difference in dating resolution is indicative of different error calculation protocol and instrumentation between labs. 
Groups 1 and 3 had sufficient sample depth to make up substantial chronologies. Group 3 is comprised of a combination of samples from all our sampling locations; group 1 consists of material from the Bosna River and Oštra Luka gravel beds only. The midpoint for the last decade sampled for wiggle-matching group 1 falls in the range $1588-1551 \mathrm{cal} \mathrm{BC}$ at $95 \%$ confidence. This puts the start of this 321-year group between 1909 and 1872 cal BC. Dates obtained for group 3 produced a less accurate fit than was achieved for group 1 as a number of the samples hit plateaus in the calibration curve. The end date for the sequence was modeled between 2113 and 1965 cal BC. This would put the start of the sequence between 2566 and 2418 cal BC. Figures $2 \mathrm{a}$ and $2 \mathrm{~b}$ show the OxCal13 wiggle-match results for the two chronologies.

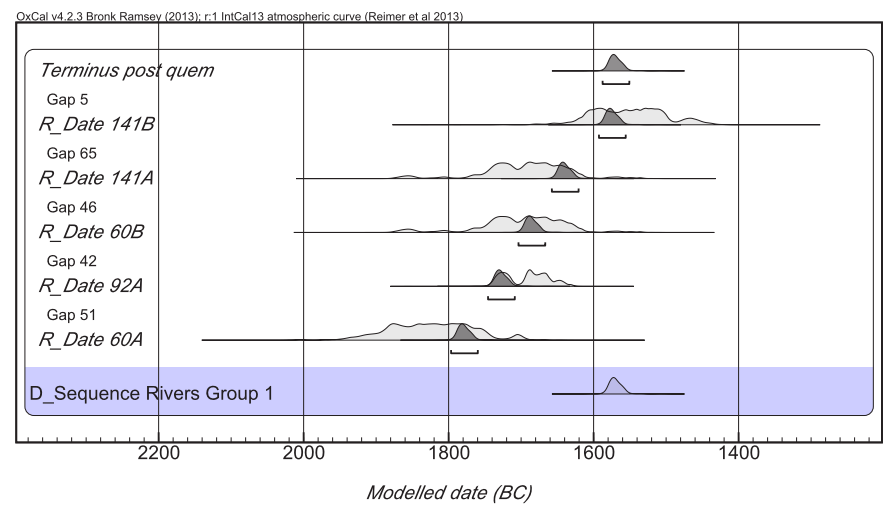

Figure 2a. OxCal multiplot wiggle-match using IntCal13. Shows a modeled placement for the end of group 1 in the range $1588-1551$ cal BC at $95 \%$ certainty.

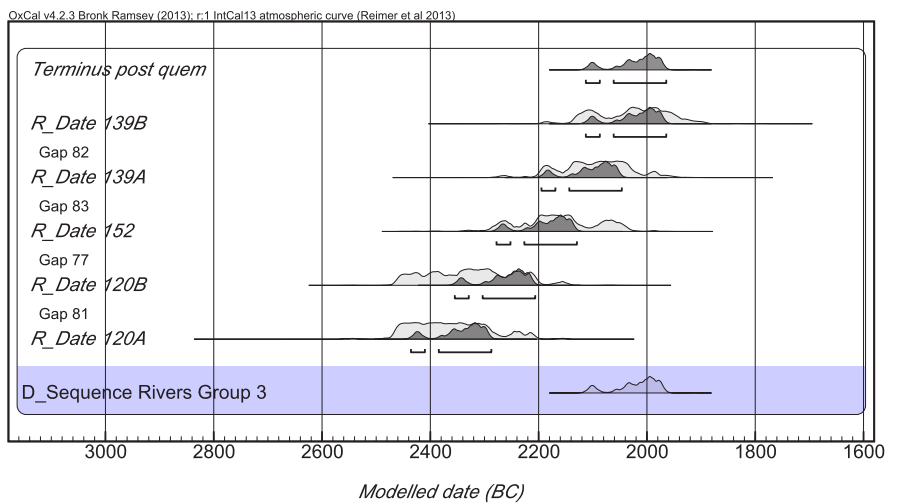

Figure 2b. OxCal multiplot wiggle-match using IntCal13 shows a modeled placement for the end of group 3 in the range $2113-1965$ cal BC at $95 \%$ certainty, or in the range $2062-1965 \mathrm{cal} \mathrm{BC}$ at $83 \%$ certainty.

\section{DISCUSSION}

Our research so far has shown that the material from these gravel deposits is spread through time over the last ca. 8000 years, with the most recent samples (from the Bosna River) having been washed into burial position sometime after AD 1334 based on a possible dendrochronological placement, or following the AD 1278-1406 range provided by ${ }^{14} \mathrm{C}$ dating. The oldest samples retrieved so far come from the Oštra Luka gravel beds (sample 25, which dates between 6072-5894 cal BC) and the Krapina and Sava rivers in the Zagreb region (samples 151, 208, 236, 262, which collectively date between 5983-5747 cal BC). Samples originating from the Sava River cover the biggest range of time periods, from 59835747 cal BC to cal AD 1018-1107. So far nothing from the Oštra Luka gravel beds or Krapina River has been dated as more recent than 2113-1965 cal BC. In the case of the Oštra Luka gravel beds, where river flow has clearly not occurred for a long time, this date may reflect the last period after which silting up occurred and the river channel meandered in another direction.

The time periods represented indicate excellent potential for building a new, continuous long master chronology for the region, especially with the addition of other new chronologies (Ważny et $a l$. , unpublished) from nearby archaeological sites such as Roman period Sisak (Durman et al. 2009) and Okuje, and Late Bronze Age Čepinski Martinci-Dubrava (Kalafatić 2009) (Figure 3). The approximate dates provided for the groups so far, in particular the two largest groups, 1 and 3, correlate broadly with some significant time periods in terms of human and environmental interactions in the wider region, which in turn are argued by many researchers to link with a range of increasingly recognized periods of abrupt climatic change (e.g. Bond et al. 1997; Bianchi and McCave 1999; Hu et al. 1999; Magny et al. 2003; Mayewski et al. 2004; Bout-Roumazeilles et al. 2007) on a global to hemispheric scale.

It would seem that our oldest samples date to around the time pollen studies from lagoons on Mljet island, off the Croatian coast, perhaps the closest paleoenvironmental data to our extraction sites (albeit in a Mediterranean coastal setting), identify abrupt changes in the pollen record (ca. 8200 and 7600 BP; Jahns

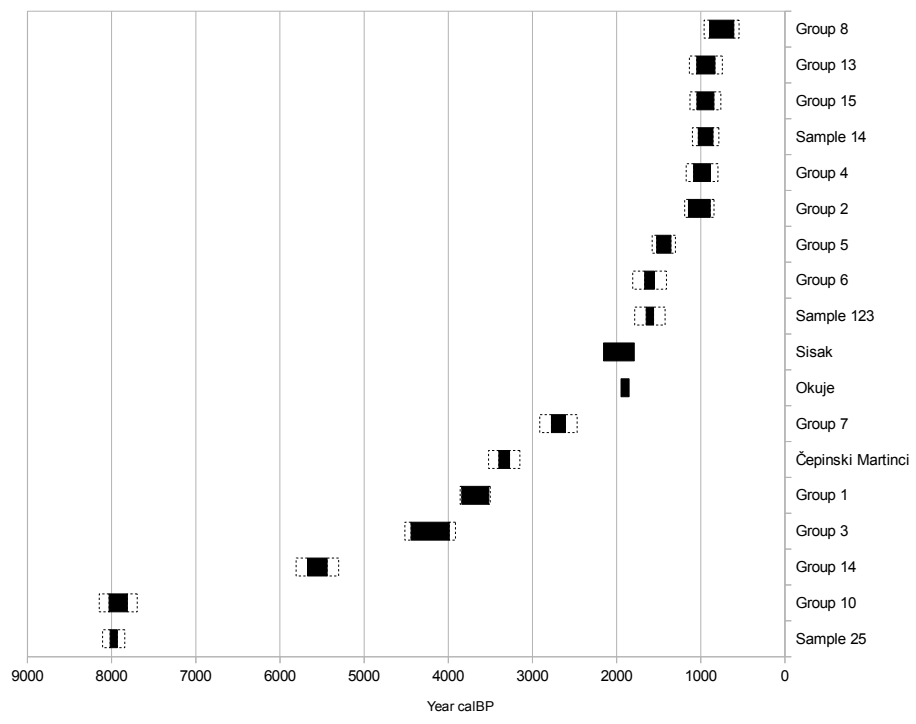

Figure 3. Temporal placements of floating oak chronologies for the study region, subfossil oak groups, single samples, and archaeological chronologies. Solid bars denote the actual length of the chronologies positioned at the midpoint of the ${ }^{14} \mathrm{C}$ range, which is shown with a dotted outline. Note that for the archaeological materials from Sisak and Okuje the placement is based on preliminary dendrochronological crossmatching, and for Cepinski Martinci-Dubrava an approximate archaeologically derived age range for the well from which the wood samples came between 1450 and 1200 BC (H. Kalafatić, personal communication, 2014). 
and van den Bogaard 1998), with similar changes for the wider region identified in multiple proxy paleoenvironmental records (e.g. Berger and Guilaine 2009; Bordon et al. 2009; Sadori et al. 2011). During this time, ca. 8250 and 7900 BP, Bonsall et al. (2002) have linked riverbank site abandonment along the Danube with a period of increased flooding. Further, they suggest that the timing of the Mesolithic-Neolithic transition in the northern Balkans may have been driven to some extent by these flood conditions. In this case, climate-related flooding may have had a significant impact on human settlement and use of riverine environments in southeast Europe during the middle Holocene. Their study identifies an "urgent need for more research into the long-term flood histories of European rivers to achieve better chronological and spatial control of individual flood episodes." The preliminary data sets presented here provide a first step towards this. The sample depth for group 10 must now be significantly increased so that a proper evaluation of the dates after which flood events must have occurred can be carried out. Sapwood is generally not preserved for this material and so the potential to get accurate felling dates for groups of trees beyond a terminus post quem for separate flood events is limited; however, there is some interesting potential within the tree-ring series themselves. Many samples contain growth releases (see Figure 4), which indicate a sudden change to more favorable conditions in the growth environment. We hypothesize that these events, when sufficiently replicated and studied as part of a dendrochronologically dated sequence, could be indicative of flooding and be used to construct more precisely dated records of when floods occurred. Another possibility might be to utilize commonly grouped pith dates as indicative of phases of post-flooding germination; however, this approach will require much substantiation and more targeted, strategic in situ sampling (e.g. consistent sampling height from the trunk) if we are to imply that the pith in the sample can be taken to represent germination.

Group 3, our third oldest and best replicated group, dates to $2113-1965$ cal BC (4062-3914 BP) and is 453 years long. This would put the first ring of the sequence (sample 213), which is about three rings from the pith, between 4515-4367 BP. Three other samples, all from the Sava River, are close to the pith at this date.

Although, as previously mentioned, no sapwood is preserved for the group 3 samples, the terminus post quem dates for this group appear to cluster around four points in time, ca. 4062-3914, 4123-3975, 4205-4057, and 4304-4156 BP. We hope to further increase this data set to examine these groupings more closely, as this time period, the beginning of the Bronze Age (ca. $4400 \mathrm{yr}$ $\mathrm{BP}$ in this region), coincides with the period of rapid onset climate variability identified in a variety of paleoenvironmental and anthropogenic records globally ca. 4200 BP (e.g. Weiss 1997; Cullen et al. 2000; Staubwasser 2003; Wenxiang and Tungsheng 2004). In some regions, the changes around this time are specifically linked with excessive flooding (e.g. Huang et al. 2011; Magny et al. 2012; Vanniere et al. 2013), and Leuschner et al. $(2000,2002)$ report a distinct germination phase in subfossil oaks

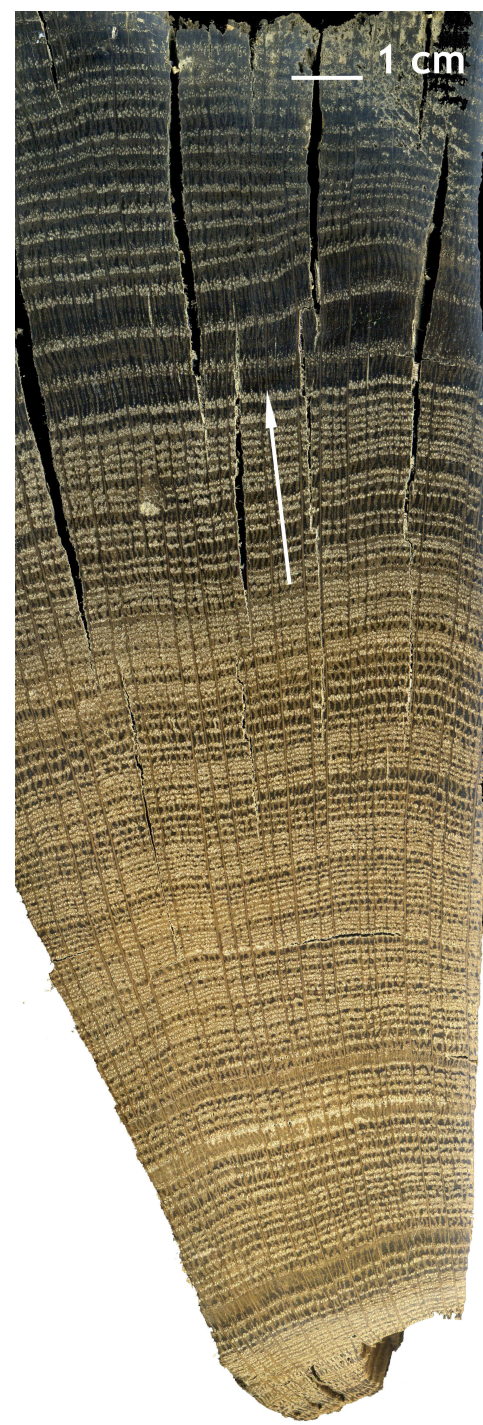

Figure 4. Sample 27 from the Oštra Luka gravel beds shows a sudden growth release (indicated by the arrow). One possible hypothesis is that the tree was growing in a dense forest near the banks of the river when a flood event occurred, sweeping away smaller vegetation and trees growing closer to the river. As a result, this surviving tree was left with improved growth conditions, more light and more nutrients (deposited by the flood waters). This hypothesis will be further tested once a sufficiently large number of crossmatching samples can be demonstrated to include similar anomalies.

from Main and Danube river gravels at this time. The fact that the group centered around 4200 BP shows good crossmatching between wood samples from the Orašje, Osijek, and the Krapina regions, which today have strong climatic differences, may be indicative of the larger scale or more dramatic climatic forcings in play during this time period.

Prospects for connecting group 3 with the second best replicated group, group 2, for a continuous sequence up to ca. 1588-1551 cal BC (3537-3500 BP) are good, with the gap between the two groups apparently fewer than 100 or so years. Group 2 also covers a time period during which there are chronological issues that 
might be addressed by the presence of a new absolutely dated treering sequence. The sequence is within ca. 40 years of covering the full range of possible dates suggested for the eruption of Thera by both conventional archaeological dating (ca. 1535-1525 BC, e.g. Wiener 2012) and ${ }^{14} \mathrm{C}$ wiggle-matching of various materials from stratigraphic contexts related to the eruption (e.g. 1627-1600 cal BC at $95 \%$ confidence: Friedrich et al. 2006; 1668-1585 cal BC at $95 \%$ confidence: Manning et al. $2006 ; 1744-1538 \mathrm{cal} \mathrm{BC}$ at 95\% confidence: Panagiotakopulu et al. 2013). In the future, this data series may provide opportunities to explore for indications of this event, which seems to have occurred in the early summer, a time of year shown to be significant in terms of both temperature and precipitation for oak growth in this region (Čufar et al. 2014).

For the more recently dated samples, we anticipate that anthropogenic activity is likely to have had an overriding impact on flooding regimes. Sample groups 15, 14, 13, 8, 4, and 2 produced some overlaps in ${ }^{14} \mathrm{C}$ placement, which make several observed potential dendrochronological crossmatches more viable, and group 8, our most recent group, puts us within ca. 100 years of the end date of the Čufar et al. absolutely dated (AD 1456-2003) oak chronology. All this indicates good prospects for a solid connection back to the $\mathrm{BC}$ period at least within a couple of additional field seasons.

\section{CONCLUSION}

With increasing interest in the impact of abrupt climate change and extreme weather events on human societies over time, the high-resolution paleoenvironmental archives offered by treering width measurements are second to none as precise reference points from which to evaluate climate change on a "human relevant" timeframe. The preliminary data sets presented here offer real prospects of a new, multimillennial, absolutely dated treering chronology for the Balkan region.

Such a record could prove immensely valuable for a growing number of archaeological research projects in the Balkans, which are producing well-preserved wooden artifacts and timbers (e.g. Benjamin et al. 2011). An absolutely dated tree-ring chronology would also open up the possibility to overcome key chronological issues such as the Hallstatt plateau (ca. 700-400 BC) in the ${ }^{14} \mathrm{C}$ calibration curve, which currently presents problems in resolving Late Bronze Age/Early Iron Age chronologies (e.g. Teržan and Črešnar 2013) in the Balkan region.

Future work will focus on extension, replication, and - eventually - dendrochronological placement of existing chronologies with the addition of new data from archaeological samples, historic buildings, and other rivers in the region. Once the dendrochronological resource is established, we will make it available for archaeological and paleoenvironmental dating in the region as well as utilizing it to gain more highly resolved snapshots of climate change and chronology in some of the key periods of the Holocene.

\section{ACKNOWLEDGMENTS}

This project was funded by the National Science Foundation, National Geographic, and the Malcolm and Carolyn Wiener Foundation. We thank three excellent research assistants, Xan Stepp, Jacob Martin, and Nicolas Turner, for much hard work on the preparation, measurement, and metadata collection for the samples; also, Rachel Kulick and Brita Lorentzen for their assistance with field collection in 2009 and 2011, respectively. In the AMS lab, we thank Alex Leonard, Rich Cruz, and Dana Biddulph for their help with the AMS measurements and Tim Jull for providing methodological detail for the ${ }^{14} \mathrm{C}$ analysis. Above all, we thank the following collaborators: in Bosnia and Herzegovina, we offer particular thanks to Hrvoje Benković, of Abonos (http://abonos-galerija.com/abonos.php), an Orašje-based commercial company, who has gone out of his way to provide material for this project. Also in Croatia, Darko Franjić, of Močvarni hrast d.o.o. (Ltd) (http://mocvarnihrast.com/), a Susedgrad-based commercial company, and Pilana Podsused d.o.o (Ltd), a Zaprešić-based commercial company (sawmill), which provided space and recent wood for sampling; Kruno Zupčić, at the Croatian Conservation Institute, Zagreb, for underwater archaeological samples from the Kupa River in Karlovac and the Drava River in Osijek; Eduard Hudolin, Head of the Osijek Department for Conservation, Croatian Conservation Institute, for samples from Ilok; Dr Irena Radić Rossi, Department of Archaeology, University of Zadar, for samples from Roman harbor near the island of Pag (not used in this paper); Dr Hrvoje Kalafatić, Institute of Archaeology, Zagreb, for samples from the archaeological site at Čepinski MartinciDubrava. Finally, and most particularly, we thank two anonymous reviewers for their helpful and insightful improvements to this manuscript.

\section{REFERENCES}

Baillie, M. G. L., 1983. Is there a single British Isles oak tree-ring signal? In Proceedings of the 22nd Symposium on Archaeometry, April, 1982, edited by A. Aspinall, and S. E. Warren; pp. 73-82. University of Bradford, Bradford, UK.

Becker, B., 1982. Dendrochronologie und Paläoökologie subfossiler Baumstämme aus Flussablagerungen. Ein Beitrag zur nacheiszeitlichen Auenentwicklung im südlichen Mitteleuropa. In Mitteilungen der Kommission für Quartärforschung der Österreichischen Akademie der Wissenschaften. Band 5, Vienna.

Becker, B., 1983. Prehistoric dendrochronology for archaeological dating: Hohenheim oak series present to 1800BC. In Proceedings of the First International Symposium ${ }^{14} \mathrm{C}$ and Archaeology, Groningen, 1981. PACT 8:503-510.

Becker, B., 1993. An 11,000-year German oak and pine dendrochronology for radiocarbon calibration. Radiocarbon 35(1):201-213.

Becker, B., and A. Delorme, 1978. Oak chronologies for Central Europe: Their extension from medieval to prehistoric times. Radiocarbon 22(2):219-226.

Begović, V., and I. Schrunk, 2010. Endangered cultural heritage along the major rivers and adjacent wetlands in Croatia. In Remote Sensing and Geoinformation Not Only for Scientific Cooperation, edited by L. Halounova; pp. 30-42. Czech Technical University, Prague.

Benjamin, J., L. Bekić, D. Komšo, I. Koncani Uhač, and C. Bonsall, 2011. Investigating the submerged prehistory of the eastern Adriatic: Progress and prospects. In Submerged Prehistory, edited by J. Benjamin, C. Bonsall, C. Pickard, and A. Fischer; pp. 193-206. Oxbow Books, Oxford.

Berger, J. F., and J. Guilaine, 2009. The 8200 cal BP abrupt environmental change and the Neolithic transition: A Mediterranean perspective. Quaternary International 200(1):31-49. 
Bianchi, G. G., and I. N. McCave, 1999. Holocene periodicity in North Atlantic climate and deep-ocean flow south of Iceland. Nature 397(6719):515-517.

Bond, G., W. Showers, M. Cheseby, R. Lotti, P. Almasi, P. Priore, and G. Bonani, 1997. A pervasive millennial-scale cycle in North Atlantic Holocene and glacial climates. Science 278(5341):1257-1266.

Bonsall, C., M. G. Macklin, R. W. Payton, and A. Boroneant, 2002. Climate, floods and river gods: Environmental change and the Meso-Neolithic transition in southeast Europe. Before Farming 3-4:1-15.

Bordon, A., O. Peyron, A. M. Lézine, S. Brewer, and E. Fouache, 2009. Pollen-inferred Late-Glacial and Holocene climate in southern Balkans (Lake Maliq). Quaternary International 200(1):19-30.

Bout-Roumazeilles, V., N. Comboureu Nebout, O. Peyron, E. Cortijo, A. Landais, and V. Masson-Delmotte, 2007. Connection between South Mediterranean climate and North African atmospheric circulation during the last 50,000 yr BP North Atlantic cold events. Quaternary Science Reviews 26(25-28):31973215.

Brewer, P. W., 2014. Data management in dendroarchaeology using Tellervo. $R a-$ diocarbon 56(4):S79-S83; Tree-Ring Research 70(3):S70-S83.

Brewer, P. W., K. Sturgeon, L. Madar, and S. W. Manning, 2010. A new approach to dendrochronological data management. Dendrochronologia 28(2):131-134.

Bronk Ramsey, C., 2009. Bayesian analysis of radiocarbon dates. Radiocarbon 51(1):337-360.

Bronk Ramsey, C., J. van der Plicht, and B. Weninger, 2001. 'Wiggle matching' radiocarbon dates. Radiocarbon 43(2A):381-389.

Brown, D. M., M. A. R. Munro, M. G. L. Baillie, and J. R. Pilcher, 1986. Dendrochronology - The absolute Irish standard. Radiocarbon 28(2A):279-283.

Burr, G. S., D. J. Donahue, Y. Tang, J. W. Beck, L. McHargue, D. Biddulph, R. Cruz, and A. J. T. Jull, 2007. Error analysis at the NSF Arizona AMS Facility. Nuclear Instruments and Methods in Physics Research B 259(1):149-153.

Cedro, A., 2007. Tree-ring chronologies of downy oak (Quercus pubescens), pedunculate oak $(Q$. robur $)$ and sessile oak $(Q$. petraea $)$ in the Bielinek Nature Reserve: Comparison of the climatic determinants of tree-ring width. Geochronometria 26:39-45.

Cook, E. R., and L. A. Kairiukstis, L. A., editors, 1990. Methods of Dendrochronology: Applications in the Environmental Sciences. Springer, Dordrecht.

Cook, E. R., B. M. Buckley, J. G. Palmer, P. Fenwick, M. J. Peterson, G. Boswijk, and A. Fowler, 2006. Millennia-long tree-ring records from Tasmania and New Zealand: A basis for modelling climate variability and forcing, past, present and future. Journal of Quaternary Science 21(7):689-699.

Čufar, K., 2007. Dendrochronology and past human activity -A review of advances since 2000. Tree-Ring Research 63(1):47-60.

Čufar, K., M. de Luis, M. Zupančič, and D. Eckstein, 2008. A 548-year tree-ring chronology of oak (Quercus spp.) for southeast Slovenia and its significance as a dating tool and climate archive. Tree-Ring Research 64(1):3-15.

Čufar, K., M. Grabner, A. Morgós, E. Martínez del Castillo, E. Merela, and M. de Luis, 2014. Common climatic signals affecting oak tree-ring growth in SE Central Europe. Trees 28(5):1267-1277.

Cullen, H. M., S. Hemming, G. Hemming, F. H. Brown, T. Guilderson, and F. Sirocko, 2000. Climate change and the collapse of the Akkadian empire: Evidence from the deep sea. Geology 28(4):379-382.

Donahue, D. J., T. W. Linick, and A. J. T. Jull, 1990. Isotope-ratio and background corrections for accelerator mass spectrometry radiocarbon measurements. Radiocarbon 32(2):135-142.

Ducousso, A., and S. Bordacs, 2004. EUFORGEN. Technical Guidelines for genetic conservation and use for pedunculate and sessile oaks (Quercus robur and $Q$. petraea). International Plant Genetic Resources Institute, Rome; 6 pp.

Durman, A., A. Gaspari, T. Levanič, and M. Novšak, 2009. The development of the regional oak tree-ring chronology from the Roman sites in Celje (Slovenia) and Sisak (Croatia). In Tree-Rings, Kings and Old World Archaeology and Environment: Papers Presented in Honor of Peter Ian Kuniholm, edited by S. W. Manning, and M. J. Bruce; pp. 57-64. Oxbow Books, Oxford.

Eckstein, D., 2007. Human time in tree rings. Dendrochronologia 24:53-60.

Eronen, M., P. Zetterberg, K. R. Briffa, M. Lindholm, J. Meriläinen, and M. Timonen, 2002. The supra-long Scots pine tree-ring record for Finnish Lapland: Part 1, chronology construction and initial inferences. The Holocene 12(6):673-680.

Ferguson, C. W., 1969. A 7104-year annual tree-ring chronology for bristlecone pine, Pinus aristata, from the White Mountains, California. Tree-Ring Bulle- $\operatorname{tin} 29(3-4): 3-29$.

Fowler, A., G. Boswijk, and J. Ogden, 2004. Tree-ring studies on Agathis australis (kauri): A synthesis of development work on Late Holocene chronologies. Tree-Ring Research 60(1):15-29.

Friedrich, M., S. Remmele, B. Kromer, J. Hoffmann, M. Spurk, K. F. Kaiser, C. Orcel, and M. Kuppers, 2004. The 12,460-year Hohenheim oak and pine tree-ring chronology from central Europe-A unique annual record for radiocarbon calibration and paleoenvironmental reconstructions. Radiocarbon 46(3):1111-1122.

Friedrich, W. L., B. Kromer, M. Friedrich, J. Heinemeier, T. Pfeiffer, and S. Talamo, 2006. Santorini eruption radiocarbon dated to $1627-1600$ BC. Science 312(5773):548-548.

Gajić-Čapka, M., 1991. Short-term precipitation maxima in different precipitation climate zones of Croatia, Yugoslavia. International Journal of Climatology 11(6):677-687.

Gričar, J., 2010. Xylem and phloem formation in sessile oak from Slovenia in 2007. Wood Research 55(4):15-22.

Gričar, J., 2013. Influence of temperature on cambial activity and cell differentiation in Quercus sessiliflora and Acer pseudoplatanus of different ages. Drvna Industrija 64(2):95-105.

Griggs, C. B., P. I. Kuniholm, M. W. Newton, J. D. Watkins, and S. W. Manning, 2009. A 924-year regional oak tree-ring chronology for north central Turkey. In Tree-Rings, Kings and Old World Archaeology and Environment: Papers Presented in Honor of Peter Ian Kuniholm, edited by S. W. Manning, and M. J. Bruce; pp. 71-79. Oxbow Books, Oxford.

Grudd, H., K. R. Briffa, W. Karlén, T. S. Bartholin, P. D. Jones, and B. Kromer, 2002. A 7400-year tree-ring chronology in northern Swedish Lapland: Natural climatic variability expressed on annual to millennial timescales. The Holocene 12(6):657-665

Haneca, K., T. Ważny, J. Van Acker, and H. Beeckman, 2005. Provenancing Baltic timber from art historical objects: Success and limitations. Journal of Archaeological Science 32(2):261-271.

Haneca, K., K. Čufar, and H. Beeckman, 2009. Oaks, tree-rings and wooden cultural heritage: A review of the main characteristics and applications of oak dendrochronology in Europe. Journal of Archaeological Science 36(1):1-11.

Hillam, J., R. A. Morgan, and I. Tyers, 1987. Sapwood estimates and the dating of short ring sequences. In Applications of Tree-Ring Studies: Current Research in Dendrochronology and Related Studies, edited by R. G. W. Ward; pp. 165-185. BAR International Series volume 333, Archaeopress, Oxford.

Hu, F. S., D. Slawinski, H. E. Wright Jr., E. Ito, R. G. Johnson, K. R. Kelts, R. F. McEwan, and A. Boedigheimer, 1999. Abrupt changes in North American climate during early Holocene times. Nature 400(29):437-440.

Huang, C. C., J. Pang, X. Zha, H. Su, and Y. Jia, 2011. Extraordinary floods related to the climatic event at 4200 a BP on the Qishuihe River, middle reaches of the Yellow River, China. Quaternary Science Reviews 30(3):460-468.

Jahns, S., and C. van den Bogaard, 1998. New palynological and tephrostratigraphical investigations of two salt lagoons on the island of Mljet, south Dalmatia, Croatia. Vegetation History and Archaeobotany 7(4):219-234.

Jansma, E., P. Brewer, and I. Zandhuis, 2010. TRiDaS 1.1: The tree-ring data standard. Dendrochronologia 28(2):99-130.

Jull, A. J. T., G. S. Burr, J. W. Beck, G. W. L. Hodgins, D. L. Biddulph, L. R. McHargue, and T. E. Lange, 2008. Accelerator mass spectrometry of longlived light radionuclides. In "Analysis of Environmental Radionuclides," edited by P. Povinec; pp. 241-262. Radioactivity in the Environment, volume 11, Elsevier, Amsterdam.

Kalafatić, H., 2009. Rescue excavations of the Čepinski Martinci-Dubrava site on the Beli Manastir-Osijek-Svilaj Motorway Route in 2007 and 2008. In $A n-$ nales Instituti Archaeologici, No. 1; pp. 26-26. Institut za arheologiju, Zagreb.

Kolar, T., T. Kyncl, and M. Rybniček, 2012. Oak chronology development in the Czech Republic and its teleconnection on a European scale. Dendrochronologia 30(3):243-248.

Kuniholm, P. I., 2001. Dendrochronology and other applications of tree-ring studies in archaeology. In Handbook of Archaeological Sciences, edited by D. Brothwell, and A. M. Pollard; pp. 35-46. Wiley, London.

Kuniholm, P. I., 2008. Dendrochronology of the Byzantine world. In The Oxford Handbook of Byzantine Studies, edited by E. Jeffreys; pp. 182-192. Oxford University Press, Oxford.

Kuniholm, P. I., and C. L. Striker, 1987. Dendrochronological investigations in the 
Aegean and neighboring regions, 1983-1986. Journal of Field Archaeology 14(4):385-398.

Leuschner, H. H., M. Spurk, M. Baillie, and E. Jansma, 2000. Stand dynamics of prehistoric oak forests derived from dendrochronologically dated subfossil trunks from bogs and riverine sediments in Europe. GeoLines 11:118-121.

Leuschner, H. H., U. Sass-Klaassen, E. Jansma, M. G. L. Baillie, and M. Spurk, 2002. Subfossil European bog oaks: Population dynamics and long-term growth depressions as indicators of changes in the Holocene hydro-regime and climate. The Holocene 12(6):695-706.

Linick, T. W., H. E. Suess, and B. Becker, 1985. La Jolla measurements of radiocarbon in south German oak tree-ring chronologies. Radiocarbon 27(1):2032.

Magny, M., C. Bégeot, J. Guiot, and O. Peyron, 2003. Contrasting patterns of hydrological changes in Europe in response to Holocene climate cooling phases. Quaternary Science Reviews 22(15-17):1589-1596.

Magny, M., F. Arnaud, Y. Billaud, and A. Marguet, 2012. Lake-level fluctuations at Lake Bourget (eastern France) around 4500-3500 cal. a BP and their palaeoclimatic and archaeological implications. Journal of Quaternary Science 27(5):494-502.

Manning, S. W., C. Bronk Ramsey, W. Kutschera, T. Higham, B. Kromer, P. Steier, and E. M. Wild, 2006. Chronology for the Aegean Late Bronze Age 17001400 BC. Science 312(5773):565-569.

Mayewski, P. A., E. E. Rohling, J. C. Stager, W. Karlén, K. A. Maasch, L. D. Meeker, E. A. Meyerson, F. Gasse, S. van Kreveld, K. Holmgren, J. LeeThorp, G. Rosqvist, F. Rack, M. Staubwasser, R. R. Schneider, and E. J. Steig, 2004. Holocene climate variability. Quaternary Research 62(3):243-255.

Nicolussi, K., M. Kaufmann, T. M. Melvin, J. van der Plicht, P. Schießling, and A. Thurner, 2009. A 9111 year long conifer tree-ring chronology for the European Alps: A base for environmental and climatic investigations. The Holocene 19(6):909-920.

Panagiotakopulu, E., T. Higham, A. Sarpaki, P. Buckland, and C. Doumas, 2013. Ancient pests: The season of the Santorini Minoan volcanic eruption and a date from insect chitin. Naturwissenschaften 100(7):683-689.

Pilcher, J. R., M. G. L. Baillie, B. Schmidt, and B. Becker, 1984. A 7,272-year tree-ring chronology for western Europe. Nature 312(5990):150-152.

Reimer, P. J., E. Bard, A. Bayliss, J. W. Beck, P. G. Blackwell, C. Bronk Ramsey, C. E. Buck, H. Cheng, R. L. Edwards, M. Friedrich, P. M. Grootes, T. P. Guilderson, H. Haflidason, I. Hajdas, C. Hatté, T. J. Heaton, D. L. Hoffmann, A. G. Hogg, K. A. Hughen, K. F. Kaiser, B. Kromer, S. W. Manning, M. Niu, R. W. Reimer, D. A. Richards, E. M. Scott, J. R. Southon, R. A. Staff, C. S. M. Turney, and J. van der Plicht, 2013. IntCal13 and Marine13 radiocarbon age calibration curves 0-50,000 years cal BP. Radiocarbon 55(4):1869-1887.

Sadori, L., S. Jahns, and O. Peyron, 2011. Mid-Holocene vegetation history of the central Mediterranean. The Holocene 21(1):117-129.

Salzer, M. W., M. K. Hughes, A. G. Bunn, and K. F. Kipfmueller, 2009. Recent unprecedented tree-ring growth in bristlecone pine at the highest elevations and possible causes. Proceedings of the National Academy of Sciences of the USA 106(48):20,348-20,353.

Spurk, M., M. Friedrich, J. Hofmann, S. Remmele, B. Frenzel, H. H. Leuschner, and B. Kromer, 1998. Revisions and extension of the Hohenheim oak and pine chronologies: New evidence about the timing of the Younger Dryas/Preboreal transition. Radiocarbon 40(3):1107-1116.

Staubwasser, M., F. Sirocko, P. M. Grootes, and M. Segl, 2003. Climate change at the $4.2 \mathrm{ka}$ BP termination of the Indus valley civilization and Holocene south Asian monsoon variability. Geophysical Research Letters 30(8):1425, doi:10.1029/2002GL016822.

Tegel, W., R. Elburg, D. Hakelberg, H. Stäuble, and U. Büntgen, 2012. Early Neolithic water wells reveal the world's oldest wood architecture. PLoS One 7(12):e51374, doi:101371/journal.pone.0051374.

Teržan, B., and M. Črešnar, 2013. Absolute Dating of the Bronze and Iron Ages in Slovenia. National Museum of Slovenia, Ljubljana.

Ufnalski, K., 2006. Teleconnection of 23 modern chronologies of Quercus robur and Q. petraea from Poland. Dendrobiology 55:51-56.

Vanniere, B., M. Magny, S. Joannin, A. Simonneau, S. B. Wirth, Y. Hamann, and F. S. Anselmetti, 2013. Orbital changes, variation in solar activity and increased anthropogenic activities: Controls on the Holocene flood frequency in the Lake Ledro area, Northern Italy. Climate of the Past 9(3):1193-1209.

Ważny, T., 1990. Aufbau und Anwendung der Dendrochronologie für Eichenholz in Polen. Ph.D. dissertation, University of Hamburg.

Ważny, T., and D. Eckstein, 1991. The dendrochronological signal of oak (Quercus spp.) in Poland. Dendrochronologia 9:35-49.

Ważny, T., B. Lorentzen, N. Köse, Ü. Akkemik, Y. Boltryk, T. Güner, J. Kyncl, T. Kyncl, C. Nechita, S. Sagaydak, and J. Kamenova Vasileva, 2014. Bridging the gaps in tree-ring records: Creating a high-resolution dendrochronological network for Southeastern Europe. Radiocarbon 56(4):S39-S50; Tree-Ring Research 70(3):S39-S50.

Weiss, H., 1997. Late third millennium abrupt climate change and social collapse in West Asia and Egypt. In Third Millennium BC Climate Change and Old World Collapse; pp. 711-723. Springer, Berlin.

Wenxiang, W., and L. Tungsheng, 2004. Possible role of the "Holocene Event 3" on the collapse of Neolithic cultures around the Central Plain of China. Quaternary International 117(1):153-166.

Wiener, M. H., 2012. Problems in the measurement, calibration, analysis and communication of radiocarbon dates (with special reference to the prehistory of the Aegean world). Radiocarbon 54(3-4):423-434. 